Check for updates

Cite this: RSC Adv., 2018, 8, 14268

\title{
Near infrared dye loaded copper sulfide-apoferritin for tumor imaging and photothermal therapy
}

\author{
Yuanyuan He, $\dagger^{\mathrm{a}}$ Yuanzhi Shen, $\dagger^{\mathrm{a}}$ Siqi Zhou, ${ }^{\mathrm{b}}$ Yihui $\mathrm{Wu},{ }^{\mathrm{c}}$ Zhenwei Yuan, ${ }^{\mathrm{a}}$ Chen Wei, ${ }^{\mathrm{a}}$ \\ Lijuan Gui, ${ }^{a}$ Yisha Chen, ${ }^{a}$ Yueqing Gu${ }^{a}$ and Haiyan Chen (DD *a
}

Development of photothermal agents for imaging-guided photothermal therapy (PTT) has been of great interest in the field of nanomedicine. CuS-apoferritin was prepared by a biomimetic synthesis method by using the inside cavity of apoferritin to control the size of CuS nanoparticles. Then, a water-soluble near infrared (NIR) dye (MBA) was bound with CuS-apoferritin, forming a nanocomplex (CuS-apoferritin-MBA) with greatly enhanced photothermal conversion efficiency compared to CuS-apoferritin. The unique optical behavior of CuS-apoferritin-MBA enables fluorescence imaging and photothermal therapy at separated optical wavelengths both, with optimized performances. CuS-apoferritin-MBA was then utilized as a photothermal agent for imaging-guided photothermal therapy in tumor-bearing mouse models. As revealed by in vivo fluorescence imaging, CuS-apoferritin-MBA showed high tumor uptake owing to an enhanced permeability and retention effect and the active targeting of apoferritin. In vivo photothermal therapy experiments indicated that tumors could be ablated by combining CuSapoferritin-MBA with irradiation of an $808 \mathrm{~nm}$ laser. Thus, our work presents a safe, simple photothermal nanocomplex, promising for future clinical translation in cancer treatment.

Received 29th January 2018
Accepted 26th March 2018

DOI: 10.1039/c8ra00911b

rsc.li/rsc-advances applications due to concerns regarding their potential longterm toxicity. Recently, a number of organic conjugated nanomaterials have also attracted significant attention as PTT agents. $^{16-19}$

Apoferritin, free iron ions of ferritin, is a four-helix bundle protein of around 200 amino acids that forms a cage of 24 subunits arranged in octahedral 432 symmetry, ${ }^{20}$ with an outer diameter of roughly $12 \mathrm{~nm}$ and an inner diameter of $8 \mathrm{~nm}$. Apoferritin cages can be reversibly disassembled when the $\mathrm{pH}$ becomes extremely acidic $(\mathrm{pH} 2-3)$ or basic $(\mathrm{pH} 10-12){ }^{21,22}$ Moreover, the ferritin cage is resistant to denaturants, including heating to high temperatures $\left(>80{ }^{\circ} \mathrm{C}\right) .{ }^{23}$ The hollow cavity of apoferritin is a perfect nanoreactor with a fixed volume for biomimetic synthesis. Last but not least, ferritin itself showed superior tumor targeting capability. ${ }^{24}$ In addition, apoferritin, can specifically bind to cells expressing transferrin receptor 1 (TfR1), a potential new target in cases of human leukemia and lymphoma. ${ }^{25,26}$ In addition to its favorable encapsulation capacity, apoferritin can also bind specifically to different cells due to the presence of ferritin receptors on the surfaces of various cells. ${ }^{27,28}$ In addition to SCARA $5,{ }^{29}$ only one FRT receptor in human cells, TfR1, has been shown to bind both FRT (via binding with $\mathrm{H}$-subunit of the protein) and transferrin. The internalization of apoferritin is performed by receptor-mediated endocytosis during the acidification of endosome; thus, the cargo is released gradually.

In this paper, water-soluble CuS NPs were selected as an effective photothermal agent due to their strong NIR 
photothermal conversion efficiency. Apoferritin was used as a biotemplate to control the size and enhance biocompatibility of CuS. Moreover, a NIR dye (MBA) was used to increase photothermal efficiency. Both cells and mouse models were successfully used to evaluate the effectiveness of CuS apoferritin-MBA guided photothermal therapy. This nanocomplex CuS-apoferritin-MBA proved to have a promising potential for clinically transferable imaging based photothermal therapy.

\section{Materials and methods}

\subsection{Materials}

Apoferritin and $\mathrm{CuCl}_{2} \cdot 2 \mathrm{H}_{2} \mathrm{O}$ were purchased from SigmaAldrich (MO, USA). $\mathrm{Na}_{2} \mathrm{~S}$ was purchased from Sinopharm Chemical Reagent Co., Ltd. MBA (MW = 768) was synthesized in our laboratory. 1-Ethyl-3-[3-dimethylaminopropyl] carbodiimide hydrochloride (EDC) and $N$-hydroxysuccinimide (NHS) were purchased from Bide Pharmatech Ltd. (Shanghai, China). 3-(4,5-Dimethylthialzol-2-yl)-2,5-diphenyltetrazolium bromide (MTT), RPMI-1640, fetal bovine serum (FBS), penicillin, streptomycin, and trypsin-EDTA were purchased from Gibco (Life Technologies, Shanghai, China). The reagents in this study were used without further purification.

\subsection{Synthesis of CuS-apoferritin nanoparticles}

CuS-apoferritin NPs were synthesized according to a previous report with some modifications. ${ }^{30} 0.25 \mathrm{~mL}$ of $\mathrm{CuCl}_{2} \cdot 2 \mathrm{H}_{2} \mathrm{O}(25$ $\mathrm{mM}$ ) solution was added into $0.5 \mathrm{~mL}$ of $1.0 \mathrm{mg} \mathrm{mL}^{-1}$ apoferritin with forceful stirring for $1 \mathrm{~h}$, and then the solution was kept at room temperature for another $20 \mathrm{~min}$. Apoferritin- $\mathrm{Cu}^{2+}$ mixture was purified by filtration through a $10 \mathrm{kDa}$ cutoff spin by using $0.1 \%$ sodium acetate solution as eluent and redissolved in $0.5 \mathrm{~mL}$ of ultrapure water with sonication. Then, $0.25 \mathrm{~mL}$ of $\mathrm{Na}_{2} \mathrm{~S}(25 \mathrm{mM})$ aqueous solution was added to the above solution with stirring at $60{ }^{\circ} \mathrm{C}$ for $1 \mathrm{~h}$. The mixture then was transferred to an ice bath to stop the reaction. The product was purified with filtration through a $100 \mathrm{kDa}$ cutoff, and then redissolved in ultrapure water with sonication for further use.

\subsection{Synthesis of CuS-apoferritin-MBA nanocomplex}

Synthesis methods and characterization of the $2-((E)-2-((E)-2-((2-$ carboxyethyl)thio)-3-(2-((E)-3,3-dimethyl-1-(3-sulfopropyl)

indolin-2-ylidene) ethylidene)cyclohex-1-en-1-yl)vinyl)-3,3dimethyl-1-(3-sulfopropyl)-3H-indol-1-ium (MBA), was reported earlier by our research group. ${ }^{31}$ MBA was immobilized onto CuSapoferritin using coupling agents (EDC and NHS) to increase the reaction yield. MBA $(1.0 \mathrm{mg})$ in $1.0 \mathrm{~mL}$ of PBS was activated with EDC and NHS (molar ratio of MBA: EDC: NHS is $1: 1.5: 1.5$ ) at room temperature in the dark for $2 \mathrm{~h}$. Then, 200 $\mu \mathrm{L}$ of activated solution of MBA was added into CuS-apoferritin aqueous solution ( $1 \mathrm{mg} \mathrm{mL}{ }^{-1}$ ) and stirred in the dark for $12 \mathrm{~h}$. The CuS-apoferritin-MBA nanocomplexes were obtained after dialyzing the solution in a dialysis bag (MWCO 8000-14000).

\subsection{Morphology and optical characterization}

The morphology of CuS-apoferritin and CuS-apoferritin-MBA were studied using a FEI Tecnai G2F20 transmission electron microscope (TEM) with a $200 \mathrm{kV}$ field emission gun. The TEM samples were prepared by drop casting an aqueous solution of CuS-apoferritin and CuS-apoferritin-MBA $\left(500 \mu \mathrm{g} \mathrm{mL}^{-1}\right)$ onto 400-mesh carbon-coated copper grids and the excessive solvent was immediately and fully evaporated before the TEM investigation. The absorption and fluorescence spectra of these samples (apoferritin, CuS-apoferritin, MBA and CuS-apoferritinMBA) were detected by using a Lambda 25 UV-vis spectrophotometer (PE, US) and fluorescence spectrometer (PE, US), respectively. The Fourier transform infrared (FTIR) spectra of CuS-apoferritin and CuS-apoferritin-MBA were recorded by FTIR spectrometer (Nicolet ECO 2000, USA).

\subsection{Cellular experiments}

2.5.1. Cell culture. Human cell lines U87MG (malignant glioma), MCF-7 (breast cancer), and L02 (normal liver cell line) were obtained from the American Type Culture Collection (ATCC, USA). The cell lines were cultured in DMEM medium supplemented with $10 \%(\mathrm{v} / \mathrm{v})$ calf serum, penicillin (100 U $\left.\mathrm{mL}^{-1}\right)$, and streptomycin (100 $\left.\mathrm{mg} \mathrm{mL}^{-1}\right)$. Cells were maintained at $37{ }^{\circ} \mathrm{C}$ under a humidified atmosphere containing $5 \% \mathrm{CO}_{2}$.

2.5.2. Cytotoxicity evaluation of CuS-apoferritin-MBA. In vitro cytotoxicity was measured using a standard methyl thiazolyl tetrazolium (MTT) assay. For cell toxicity assay, L02, U87 MG, and MCF-7 cells were seeded into 96-well cell culture plates at $1 \times 10^{5} /$ well and then incubated with various concentrations of CuS-apoferritin and CuS-apoferritin-MBA for $24 \mathrm{~h}$. The standard MTT assay was carried out to determine the relative cell viabilities.

2.5.3. Cellular affinity and photothermal effect of CuSapoferritin-MBA on U87MG cells. U87MG cells were cultured in laser confocal fluorescence microscopy (LSCM) culture dishes with a density of $5 \times 10^{5}$ cells per dish. When the whole cells took up $70 \%-80 \%$ space of the culture dishes, the cells were treated with CuS-apoferritin, MBA, and CuS-apoferritin-

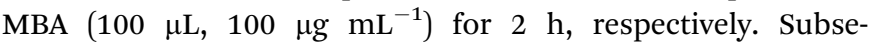
quently, the cells were washed thrice with PBS to remove free NPs. Cells were fixed in $4 \%$ formaldehyde for $15 \mathrm{~min}$ at room temperature and washed thrice with PBS. The fixed cells were observed by LSCM (FV 1000, Olympus, Japan) at $\lambda_{\text {ex }}=405 \mathrm{~nm}$ and $\lambda_{\text {em }}=647 \mathrm{~nm}$.

2.5.4. Photothermal therapy. For photothermal therapy, U87 MG cells were seeded into 96-well plates with a density of 1 $\times 10^{5}$ cells per well until adherent and then incubated with 100

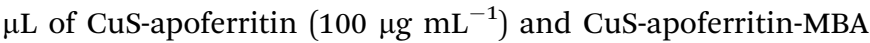
$\left(100 \mu \mathrm{g} \mathrm{mL}^{-1}\right)$ for $4 \mathrm{~h}$. The cells were irradiated by an $808 \mathrm{~nm}$ laser at different power densities $\left(0.5,0.8\right.$, and $\left.1.0 \mathrm{~W} \mathrm{~cm}^{-2}\right)$ for 4 min before the MTT assay. In addition, U87 MG cells incubated with different concentrations of CuS-apoferritin and CuSapoferritin-MBA $\left(10,20,40,60,80\right.$, and $\left.100 \mu \mathrm{g} \mathrm{mL}^{-1}\right)$ were also detected for evaluation of their photothermal effects. Then, the cells were irradiated by an $808 \mathrm{~nm}$ laser at power densities of $1 \mathrm{~W} \mathrm{~cm}^{-2}$. 
Next, in order to investigate the tumor targeting of CuSapoferritin and CuS-apoferritin-MBA, U87 MG cells were incubated with $100 \mu \mathrm{L}$ of anti-TfR for $30 \mathrm{~min}$, followed by incubating with CuS-apoferritin $\left(100 \mu \mathrm{g} \mathrm{mL} \mathrm{m}^{-1}\right)$ and CuS-apoferritin-MBA $\left(100 \mu \mathrm{g} \mathrm{mL}{ }^{-1}\right)$ for $4 \mathrm{~h}$. Then, the cells were irradiated by an $808 \mathrm{~nm}$ laser at different power densities $(0.5,0.8$, and $1.0 \mathrm{~W}$ $\mathrm{cm}^{-2}$ ) for $4 \mathrm{~min}$ before the MTT assay. Furthermore, U87 MG cells were incubated with $100 \mu \mathrm{L}$ of anti-TfR for $30 \mathrm{~min}$ followed by incubating CuS-apoferritin and CuS-apoferritin-MBA with different concentrations $\left(10 \mu \mathrm{g} \mathrm{mL}{ }^{-1}, 20 \mu \mathrm{g} \mathrm{mL}^{-1}, 40 \mu \mathrm{g} \mathrm{mL}^{-1}\right.$, $60 \mu \mathrm{g} \mathrm{mL} L^{-1}, 80 \mu \mathrm{g} \mathrm{mL}{ }^{-1}$, and $100 \mu \mathrm{g} \mathrm{mL}^{-1}$ ) were also detected for evaluation of their photothermal effects. Then, the cells were irradiated by an $808 \mathrm{~nm}$ laser at power densities of $1 \mathrm{~W} \mathrm{~cm} \mathrm{~cm}^{-2}$.

For normal apoptotic and necrotic cell analysis, U87MG cells were seeded in 24 well plates. When the whole cells took up $70-80 \%$ space of the culture dishes, they were incubated with CuS-apoferritin $\left(200 \mu \mathrm{g} \mathrm{mL}{ }^{-1}\right)$ and CuS-apoferritin-MBA $(200 \mu \mathrm{g}$ $\mathrm{mL}^{-1}$ ) for $4 \mathrm{~h}$. Then, the cells were irradiated by an $808 \mathrm{~nm}$ laser at power densities of $1 \mathrm{~W} \mathrm{~cm}{ }^{-2}$. The cells were incubated at $37{ }^{\circ} \mathrm{C}$ with $5 \% \mathrm{CO}_{2}$ for another $2 \mathrm{~h}$. Then, the cells were stained with Calcein AM/PI $\left(10 \mu \mathrm{g} \mathrm{mL} \mathrm{m}^{-1}\right)$ and incubated at $37{ }^{\circ} \mathrm{C}$ for $20 \mathrm{~min}$. After the cells were washed twice with PBS, they were imaged by a Leica fluorescent microscope (DM 5000B, Germany).

\subsection{Infrared thermal imaging}

Normal (Kunming) mice were purchased from Charles River Laboratories (Shanghai, China) for in vivo imaging investigations. All animal experiments were carried out in compliance with the Animal Management Rules of the Ministry of Health of the People's Republic of China (document no. 55, 2001) and approved by the Animal Ethics Committee of China Pharmaceutical University (Nanjing, China).

Tumor-bearing mouse models were obtained by subcutaneously injecting EAC tumor cells $\left(\sim 5 \times 10^{6}\right.$ in $50 \mu \mathrm{L}$ of PBS) into axillary fossa of the mice. When the tumor volumes reached about $100-200 \mathrm{~mm}^{3}$, the mice were immobilized for in vivo infrared thermal imaging.

$50 \mu \mathrm{L}$ of PBS, CuS-apoferritin and CuS-apoferritin-MBA were injected into tumor-bearing mice via intratumor injection. An $808 \mathrm{~nm}$ laser $\left(1.0 \mathrm{~W} \mathrm{~cm}^{-2}\right)$ was employed to perpendicularly irradiate the injected areas of mice, respectively. The infrared thermographic maps and changes were recorded by an infrared thermal imaging camera (Fluke, USA) at different time intervals (0 min, $1 \mathrm{~min}, 3 \mathrm{~min}, 5 \mathrm{~min}$, and $8 \mathrm{~min}$ ).

\subsection{Subcutaneous tumor model for imaging and therapy}

2.7.1. Animal subjects and tumor model. Normal (Kunming) mice were purchased from Charles River Laboratories (Shanghai, China) for in vivo imaging investigations. All animal experiments were carried out in compliance with the Animal Management Rules of the Ministry of Health of the People's Republic of China (document no. 55, 2001) and the guidelines for the Care and Use of Laboratory Animals of China Pharmaceutical University. To investigate the targeting ability of CuS-apoferritin-MBA, the group of female nude mice $(n=5)$ was subcutaneously injected of EAC $\left(\sim 5 \times 10^{6}\right.$ in $50 \mu \mathrm{L}$ of PBS) into the axillary fossa. As EAC tumors grew to a volume of $\sim 200 \mathrm{~mm}^{3}$, the mice were immobilized for in vivo tumor imaging.

2.7.2. Bio-distribution of CuS-apoferritin-MBA in normal mice. Normal mice $(n=5)$ were used for the bio-distribution investigation of CuS-apoferritin-MBA in vivo. In the experiment, an aqueous solution $\left(100 \mu \mathrm{L}, 2.5 \mathrm{mg} \mathrm{mL} \mathrm{mL}^{-1}\right)$ was administered into each mouse through tail vein injection. Real time imaging was then performed in a dark room using the NIR fluorescence imaging system equipped with a $660 \mathrm{~nm}$ laser. A series of fluorescence images were collected at $0.5 \mathrm{~h}, 2 \mathrm{~h}, 4 \mathrm{~h}$, $8 \mathrm{~h}, 12 \mathrm{~h}, 24 \mathrm{~h}$, and $48 \mathrm{~h}$ respectively. The mice were dissected at the corresponding time points ( $4 \mathrm{~h}, 8 \mathrm{~h}, 12 \mathrm{~h}, 24 \mathrm{~h}$, and $48 \mathrm{~h}$ ) and the fluorescence images of the organs (intestine, kidney, lung, spleen, liver, and heart) were collected to investigate the bio-distribution of CuS-apoferritin-MBA in vitro.

2.7.3. Dynamics and targeting ability of CuS-apoferritinMBA in tumor-bearing mice. CuS-apoferritin-MBA $(100 \mu \mathrm{L}$, $2.5 \mathrm{mg} \mathrm{mL}^{-1}$ ) was injected into each mouse through the vena caudalis for tracing the targeting ability of the probe toward tumors. NIR fluorescence images were collected at scheduled intervals ( $0.5 \mathrm{~h}, 2 \mathrm{~h}, 4 \mathrm{~h}, 8 \mathrm{~h}, 12 \mathrm{~h}, 24 \mathrm{~h}$, and $48 \mathrm{~h})$ within $48 \mathrm{~h}$ post-injection, and background images of the mice were taken before sample injection. To further compare the targeting ability of the probe for tumor sites, tumor fluorescence intensity at different time points was calculated using region of interest (ROI) functions of Scion Image software. The mice were also dissected at the $12 \mathrm{~h}$ post-injection and fluorescence images of their organs (tumor, intestine, kidney, lung, spleen, liver, and heart) were collected to investigate the bio-distribution of CuSapoferritin-MBA in vitro.

2.7.4. In vitro tumor tissue distribution CuS-apoferritinMBA in tumor-bearing mice. To further investigate the therapeutic effects of CuS-apoferritin-MBA, the tumors of the four groups were excised for pathological analysis after 15 days of treatment. Tumors of the mice were isolated from the mice, fixed with $10 \%$ neutral buffered formalin, and embedded in paraffin. The sliced tumor tissues $(8 \mathrm{~mm})$ were stained with Hematoxylin and Eosin (H\&E) and examined using a Positive biological microscope (Olympus, BX53).

2.7.5. Therapeutic efficacy of CuS-apoferritin-MBA in tumor-bearing mice. The EAC tumor-bearing mice were randomly assigned into five groups ( $n=5$ per group): (a) saline $(100 \mu \mathrm{L})$; (b) saline $(100 \mu \mathrm{L})$ irradiated by $808 \mathrm{~nm}$ laser; (c) CuSapoferritin $\left(100 \mu \mathrm{L}, 2.5 \mathrm{mg} \mathrm{kg}^{-1}\right)$ irradiated by the $808 \mathrm{~nm}$ laser; and (d) CuS-apoferritin-MBA (100 $\left.\mu \mathrm{L}, 2.5 \mathrm{mg} \mathrm{kg}{ }^{-1}\right)$ irradiated by the $808 \mathrm{~nm}$ laser. The power density of the $808 \mathrm{~nm}$ laser was $1.0 \mathrm{~W} \mathrm{~cm}^{-2}$ (5 min, continuous irradiation). The tumor sizes were recorded every 2 days over 15 days, with their lengths and widths measured by a digital caliper. The tumor volume was calculated according to the following formula: width ${ }^{2} \times$ length/2. To further investigate the therapeutic effects of CuS-apoferritin and CuS-apoferritin-MBA, the tumors of the four groups were excised for pathological analysis after 15 days of treatment. 


\subsection{Statistical analysis}

Significant differences were determined using the Student's $t$ test where differences were considered significant when $p<0.05$. All data are expressed as mean \pm standard error of the mean.

\section{Results and discussion}

\subsection{Synthesis and characterization of CuS-apoferritin-MBA} nanocomplex

The detailed synthesis route of MBA and CuS-apoferritin-MBA nanocomplex is shown in Fig. 1A and B. Apoferritin was used as a biotemplate to synthesize and control the size of CuS.
Apoferritin has a functional carboxyl group and amino group; herein, the activated carboxyl group of MBA was conjugated with the amino group of apoferritin via NHS/EDC.

The size and morphology of CuS-apoferritin NCs were characterized by DLS and TEM. The TEM image shown in Fig. 2A presents an explicit spherical nanocage with a diameter around $12 \mathrm{~nm}$. With the formation of $\mathrm{CuS}$ nanoparticles inside apoferritin nanocages, the core of apoferritin turns to black due to the high electron quantity of CuS NPs. The diameter distribution of CuS-apoferritin was obtained by statistically measuring their sizes in the TEM images using the plugin in Gatan Digital Micrograph (Fig. 2B). The mean diameter was calculated as 9.2

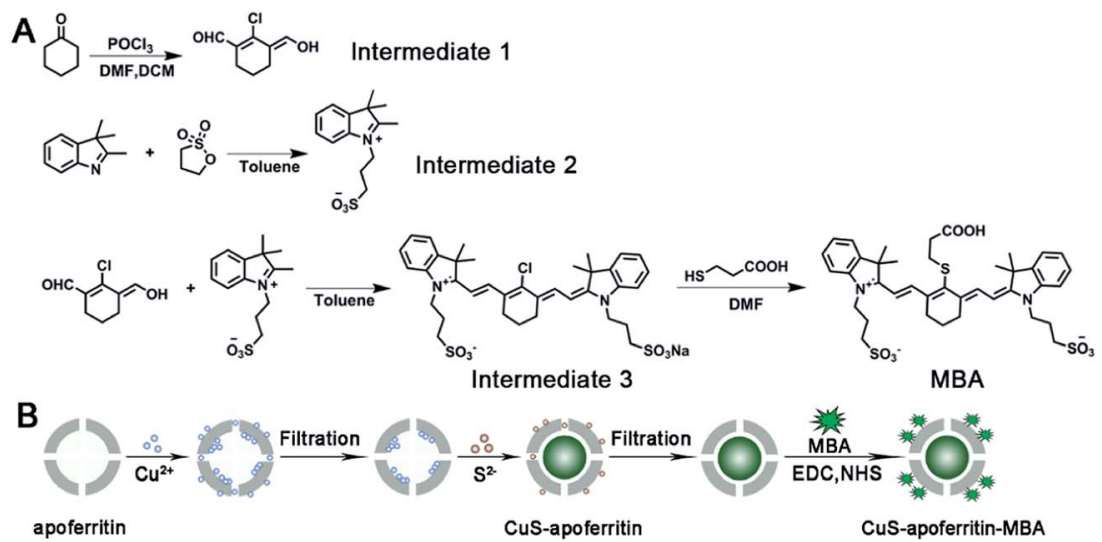

Fig. 1 The schematic synthesis routine of (A) MBA and (B) CuS-apoferritin-MBA.
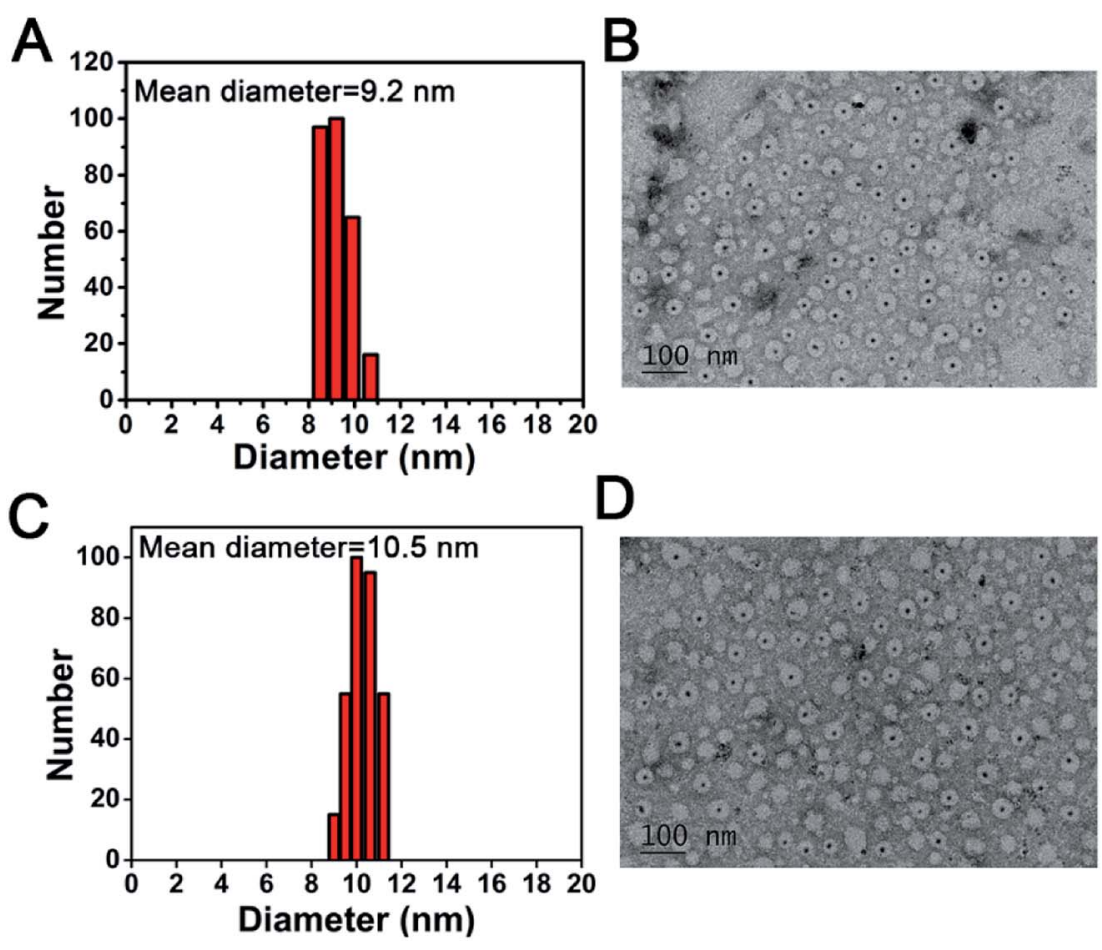

Fig. 2 (A) The size distribution of CuS-apoferritin NCs; (B) TEM image of CuS-apoferritin NCs stained with $1 \%$ uranyl acetate. A clear dark CuS core can be seen inside the apoferritin cage; (C) The size distribution of CuS-apoferritin-MBA NCs; (D) TEM image of CuS-apoferritin-MBA NCs stained with $1 \%$ uranyl acetate. 
$\pm 0.387 \mathrm{~nm}$. The TEM image shown in Fig. 2C presents an explicit spherical nanocage of CuS-apoferritin-MBA; the mean diameter was calculated as $10.5 \pm 0.252 \mathrm{~nm}$. There was no significant increase in particle size of CuS-apoferritin-MBA (Fig. 2D).

As shown in Fig. 3A, CuS-apoferritin nanoparticles have strong absorbance in the infrared region while apoferritin has no absorption. MBA and CuS-apoferritin-MBA (dissolved in PBS, $\mathrm{pH}=7.4$ ) all had a strong absorption at $780 \mathrm{~nm}$. As shown in Fig. 3B, MBA has a strong emission peak at around $810 \mathrm{~nm}$ and CuS-apoferritin-MBA has the similar emission peak around $810 \mathrm{~nm}$ in PBS. No absorption peaks were observed for CuSapoferritin. As shown in Fig. 3C, a new peak at $1708.2 \mathrm{~cm}^{-1}$ appears after MBA conjugates with CuS-apoferritin. This peak is attributed to the formation of $-\mathrm{C}=\mathrm{O}-$ of the amido bond (-NHCO-). Vibration of the benzene skeleton causes additional peaks $\left(1549.6 \mathrm{~cm}^{-1}, 1653 \mathrm{~cm}^{-1}\right)$, verifying the successful link of MBA to CuS-apoferritin. The peak at $779.8 \mathrm{~cm}^{-1}$ shows that the benzene ring is para-substituted, which is consistent with the structure of MBA. These results all can confirm the successful conjugation of MBA with CuS-apoferritin.

\subsection{Photothermal effect of CuS-apoferritin and CuS- apoferritin-MBA}

The temperature changes of CuS-apoferritin and CuSapoferritin-MBA during NIR laser irradiation $\left(0.8 \mathrm{~W} \mathrm{~cm}^{-2}, 808\right.$ $\mathrm{nm}$ ) were monitored. As shown in Fig. 4A, CuS-apoferritin possessed a temperature rise profile that is concentration dependent. For the different CuS-apoferritin aqueous solutions $\left(10,20,40,80,100\right.$, and $\left.200 \mu \mathrm{g} \mathrm{mL}{ }^{-1}\right)$, the temperature increased (from 19.5 to $51.7{ }^{\circ} \mathrm{C}$ ) at different scopes after 5 minutes of irradiation. At the concentration of $10 \mu \mathrm{g} \mathrm{mL}{ }^{-1}$, a temperature rise of over $13{ }^{\circ} \mathrm{C}$ was observed after 2 min of irradiation. At a higher concentration of $200 \mu \mathrm{g} \mathrm{mL}{ }^{-1}$, the temperature increased $36.3{ }^{\circ} \mathrm{C}$. Moreover, the maximum temperature increases of CuS-apoferritin $\left(100 \mu \mathrm{g} \mathrm{mL} \mathrm{m}^{-1}\right)$ and CuS-apoferritin-MBA $\left(100 \mu \mathrm{g} \mathrm{mL} \mathrm{mL}^{-1}\right)$ are 20.3 and $28.5{ }^{\circ} \mathrm{C}$, respectively (Fig. 4B). These results revealed that CuSapoferritin and CuS-apoferritin-MBA can be used as efficient PTT agents for tumor hyperthermia.

The infrared thermal images of CuS-apoferritin and CuSapoferritin-MBA aqueous solution after $808 \mathrm{~nm}$ laser light irradiation for different times $(1,3,5$, and $8 \mathrm{~min})$ or different concentrations (100 and $200 \mu \mathrm{g} \mathrm{mL}^{-1}$ ) are shown in Fig. $4 \mathrm{C}$ and D. During irradiation, temperature changes of the solutions were monitored by an IR thermal camera. After $1 \mathrm{~min}$ of irradiation, the temperatures of all the solutions were still below $30{ }^{\circ} \mathrm{C}$. In comparison, a more significant temperature increase was noticed for the CuS-apoferritin-MBA $\left(200 \mu \mathrm{g} \mathrm{mL}^{-1}\right)$ solutions irradiated for more than $3 \mathrm{~min}$, reaching a temperature of $36.7{ }^{\circ} \mathrm{C}$ throughout the irradiation period. After $5 \mathrm{~min}$ of irradiation, CuS-apoferritin-MBA $\left(200 \mu \mathrm{g} \mathrm{mL}^{-1}\right)$ solutions reached a temperature of nearly $40{ }^{\circ} \mathrm{C}$, then the solutions' temperatures dropped, which can be attributed to the low-photo-stability of MBA.
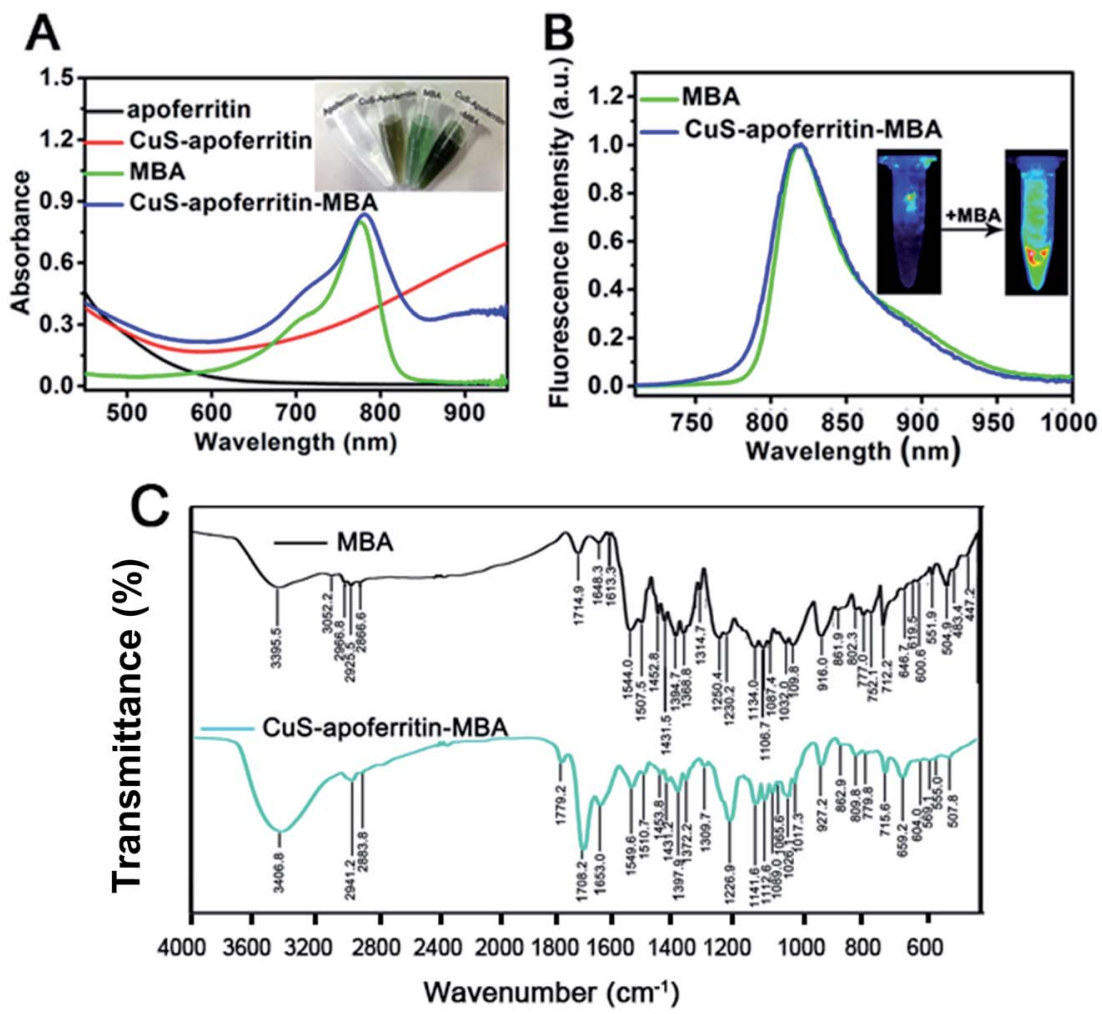

Fig. 3 (A) The absorption spectra of apoferritin, CuS-apoferritin, MBA and CuS-apoferritin-MBA; the inset photo shows the real color pictures of apoferritin, CuS-apoferritin, MBA and CuS-apoferritin-MBA; (B) the fluorescence spectra of MBA and CuS-apoferritin-MBA; the inset photos are two samples under $660 \mathrm{~nm}$ excitation; (C) the FIIR spectroscopy of MBA and CuS-apoferritin-MBA. 

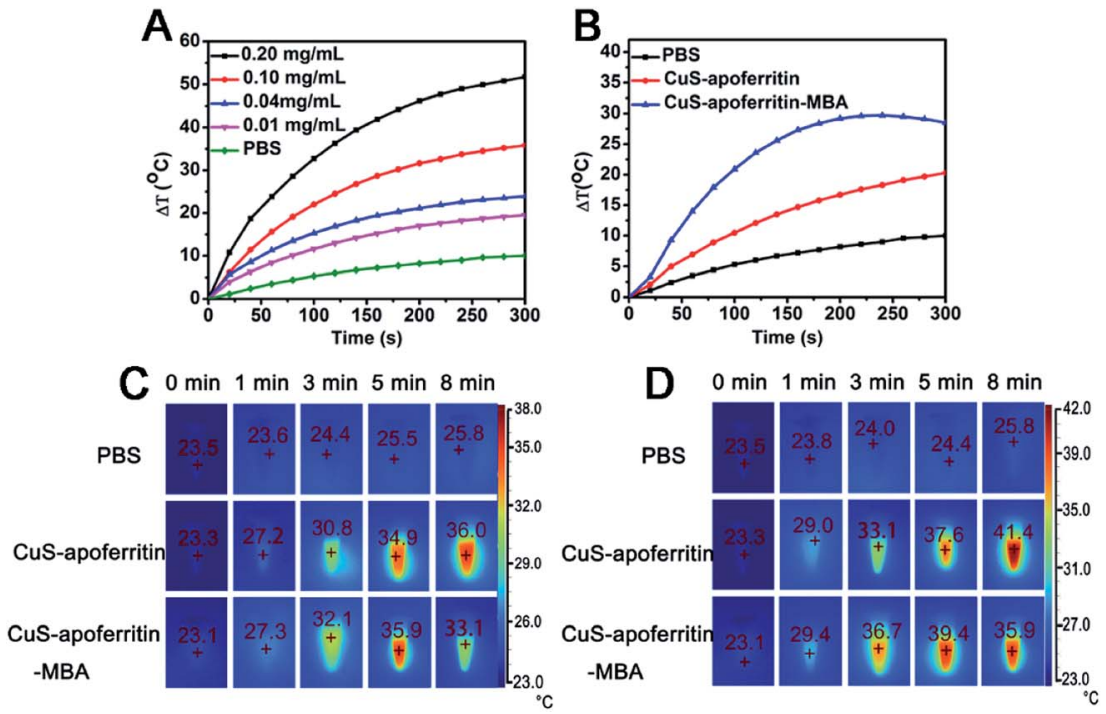

Fig. 4 The photothermal effect of (A) CuS-apoferritin and (B) CuS-apoferritin-MBA aqueous solutions irradiated by $808 \mathrm{~nm}$ laser light (0.8 W $\mathrm{cm}^{-2}$ ). The infrared thermal images of CUS-apoferritin and CUS-apoferritin-MBA aqueous solution after $808 \mathrm{~nm}$ laser light irradiated for different times $(1,3,5$, and $8 \mathrm{~min})$ at different concentrations (C) $100 \mu \mathrm{g} \mathrm{mL} \mathrm{L}^{-1}$ and (D) $200 \mu \mathrm{g} \mathrm{m}^{-1}$.

\subsection{In vitro cytotoxicity and cellular uptake studies}

The in vitro toxicity of CuS-apoferritin-MBA on L02, U87MG and MCF-7 cell lines were studied in a concentration range of 10 to $100 \mu \mathrm{g} \mathrm{mL}{ }^{-1}$. As indicated in Fig. 5A-C, all the cells maintained a high viability, even after incubation with these two nanoparticles at a high concentration $\left(100 \mu \mathrm{g} \mathrm{mL}{ }^{-1}\right)$, verifying the good biocompatibility of these two nanoparticles.

Next, the cellular uptake of CuS-apoferritin-MBA was tested on U87MG cells imaged by confocal microscopy (Fig. 5D). After $2 \mathrm{~h}$ of incubation, compared with CuS-apoferritin, CuS-
apoferritin-MBA $\left(100 \mu \mathrm{g} \mathrm{mL}^{-1}\right)$ treated cells presented a significantly stronger red fluorescence, which demonstrated that MBA can provide useful fluorescence signals for imaging the distribution of CuS-apoferritin in cell levels.

\subsection{In vitro photothermal cytotoxicity of CuS-apoferritin- MBA}

To investigate photothermal cytotoxicity, CuS-apoferritin-MBA and CuS-apoferritin-MBA were utilized as photothermal agents for in vitro cancer cell ablation under laser irradiation. As
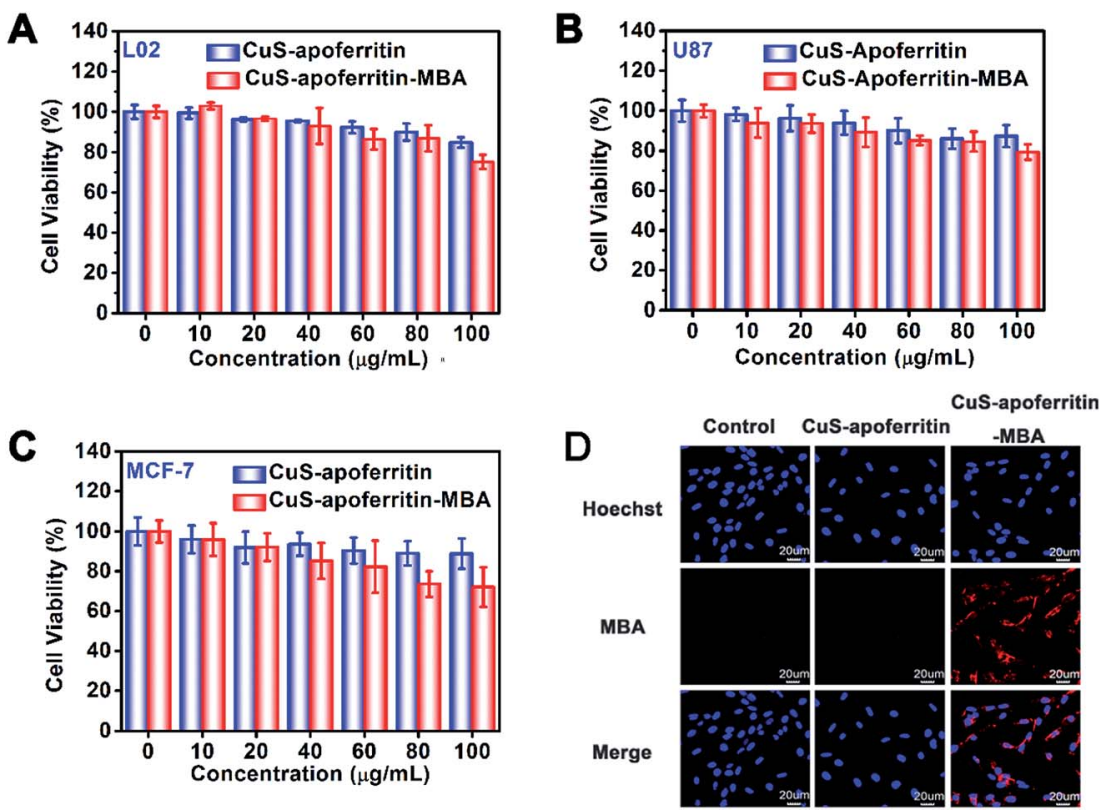

Fig. 5 MTT assay was used to qualitatively display in vitro anti-tumor activity of CuS-apoferritin and CuS-apoferritin-MBA on (A) L02, (B) U87MG, and (C) MCF-7 cell lines; (D) LSCM images of U87MG cell lines incubated with CuS-apoferritin and CuS-apoferritin-MBA for $2 \mathrm{~h}$ (the nuclei was stained with Hoechst 33342). 

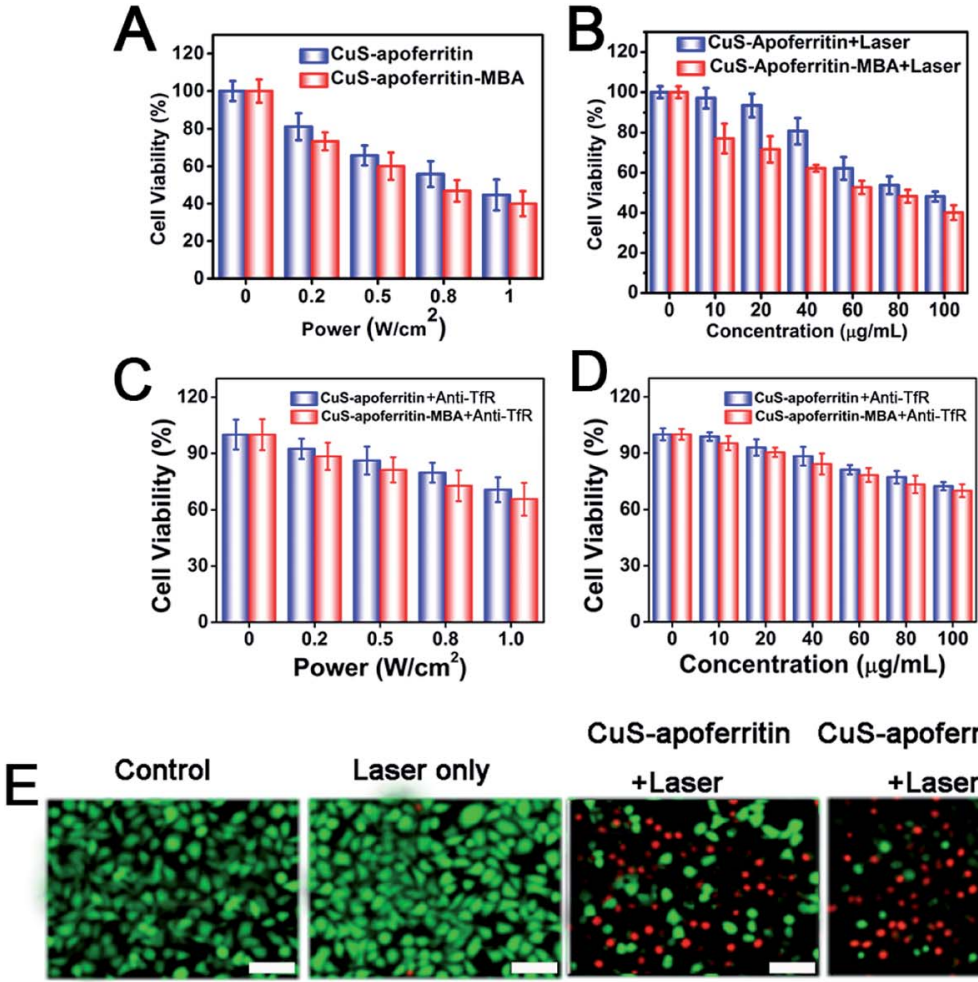

CuS-apoferritin CuS-apoferritin-MBA
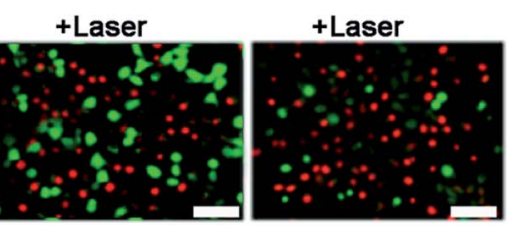

Fig. 6 (A) Cell viabilities of U87MG cells after CuS-apoferritin $\left(100 \mu \mathrm{g} \mathrm{mL} \mathrm{L}^{-1}\right)$ and CuS-apoferritin-MBA (100 $\left.\mu \mathrm{g} \mathrm{mL} \mathrm{m}^{-1}\right)$ induced photothermal ablation at different laser power densities $\left(0.2,0.5,0.8\right.$, and $1.0 \mathrm{~W} \mathrm{~cm}^{-2}$ ). (B) Cell viabilities of U87MG cells incubated with different concentrations $\left(10,20,40,80\right.$, and $\left.100 \mu \mathrm{g} \mathrm{mL}^{-1}\right)$ of CuS-apoferritin and CuS-apoferritin-MBA under exposure to the $808 \mathrm{~nm}$ laser at a power density of $1 \mathrm{~W} \mathrm{~cm}{ }^{-2}$. (C) Cell viabilities of U87MG cells after CuS-apoferritin $\left(100 \mu \mathrm{g} \mathrm{mL} \mathrm{L}^{-1}\right)$ and CuS-apoferritin-MBA $\left(100 \mu \mathrm{g} \mathrm{mL} \mathrm{L}^{-1}\right)$ with anti-TfR induced photothermal ablation at different laser power densities $\left(0.2,0.5,0.8\right.$, and $\left.1.0 \mathrm{~W} \mathrm{~cm}^{-2}\right)$. (D) Cell viabilities of U87MG cells incubated with different concentrations $\left(10,20,40,80\right.$, and $\left.100 \mathrm{~g} \mathrm{~mL}^{-1}\right)$ of CuS-apoferritin and CuS-apoferritin-MBA under exposure to the $808 \mathrm{~nm}$ laser at the a power density of $1 \mathrm{~W} \mathrm{~cm}^{-2}$. (E) Confocal fluorescence images of Calcein AM/PI co-stained U87MG cells incubated with CuS-apoferritin (100 $\mu \mathrm{g} \mathrm{mL} \mathrm{m}^{-1}$ ) and CuS-apoferritin-MBA $\left(100 \mu \mathrm{g} \mathrm{m}^{-1}\right)$ after being exposed to the $808 \mathrm{~nm}$ laser $\left(1 \mathrm{~W} \mathrm{~cm}^{-2}\right)$ for $5 \mathrm{~min}$. Error bar is $20 \mu \mathrm{m}$.

shown in Fig. 6A and B, an enhanced cancer cell ablation was observed with an increase of laser power densities or the concentrations of CuS-apoferritin and CuS-apoferritin-MBA. As shown in Fig. 6C and D, the anti-TfR occupies the transferrin receptor so that CuS-apoferritin and CuS-apoferritin-MBA can't combine with transferrin receptor. The amount of CuSapoferritin and CuS-apoferritin-MBA entering the cell was reduced, the thermal effect was lower, and there was not enough to kill more cancer cells; the cell viabilities were higher than CuS-apoferritin and CuS-apoferritin-MBA only.

Fluorescent images of Calcine AM and PI co-stained cells further confirmed the effective and specific photothermal ablation of U87MG cells induced by CuS-apoferritin and CuSapoferritin-MBA (Fig. 6E). Red fluorescence indicates dead cells and green fluorescence indicates live cells. Before $808 \mathrm{~nm}$ laser irradiation, the nanoparticles treated cells were alive. Once $808 \mathrm{~nm}$ laser was used to irradiate the CuS-apoferritin-MBA
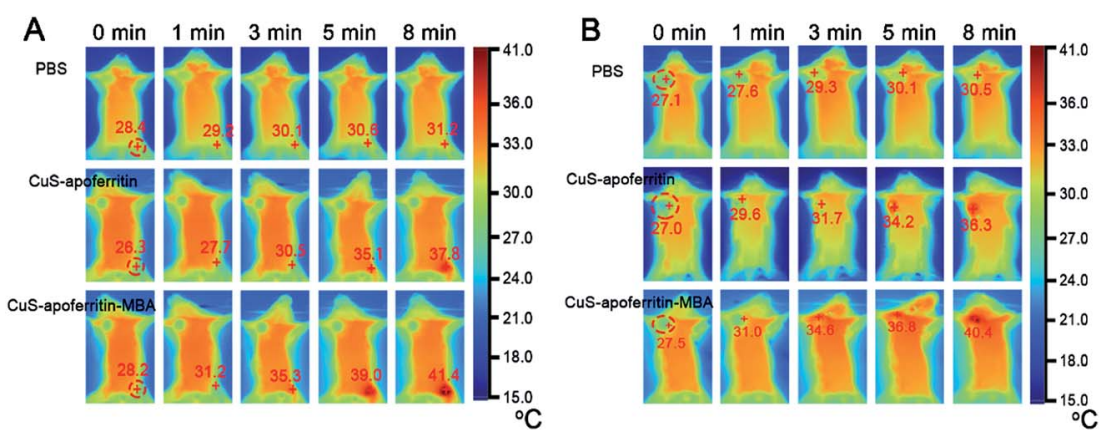

Fig. 7 The infrared thermal images of (A) normal mice and (B) EAC tumor-bearing mice injected with the PBS, CuS-apoferritin and CuS-apoferritin-MBA. 
A

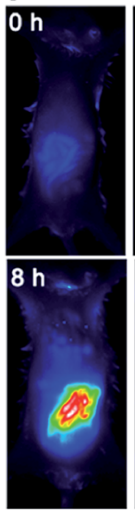

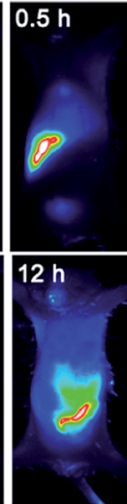
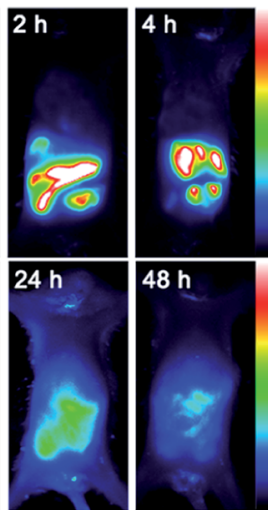

B
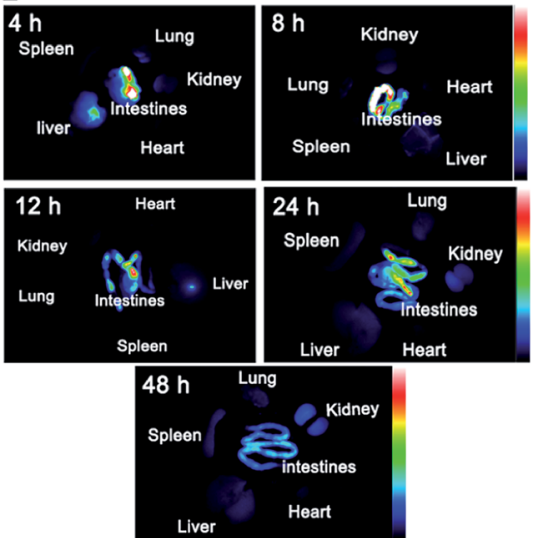

Fig. 8 (A) Dynamic distribution of CuS-apoferritin-MBA in normal mice monitored by a NIR fluorescence imaging system. (B) The ex vivo fluorescence images of isolated organs (heart, liver, spleen, lung, kidney, and intestine) from normal mice at $4 \mathrm{~h}, 8 \mathrm{~h}, 12 \mathrm{~h}, 24 \mathrm{~h}$, and $48 \mathrm{~h}$ postinjection of CuS-apoferritin-MBA.

group, a large number of cells were scalded to death by thermal energy released from the CuS-apoferritin-MBA. These results illustrate the advantage of killing cancer cells by using CuSapoferritin-MBA as a photothermal agent.

\subsection{In vivo photothermal efficacy of CuS-apoferritin-MBA}

To investigate photothermal therapeutic efficacy of CuSapoferritin-MBA, $50 \mu \mathrm{L}$ of PBS as control were injected into normal mice and tumor-bearing mice respectively. CuSapoferritin and CuS-apoferritin-MBA were injected into the right lower limb of the normal mice, respectively, and CuSapoferritin and CuS-apoferritin-MBA were also injected into the tumor in the tumor-bearing mice, respectively. As shown in Fig. 7A, within $5 \mathrm{~min}$ of laser irradiation, both the CuSapoferritin and CuS-apoferritin-MBA groups had an obvious increase of temperature. But with the same laser irradiation time, the tumor temperature of CuS-apoferritin-MBA group was enhanced more highly than that of CuS-apoferritin groups (Fig. 7B). After $1 \mathrm{~min}$ of laser irradiation, the tumors treated with CuS-apoferritin and CuS-apoferritin-MBA had
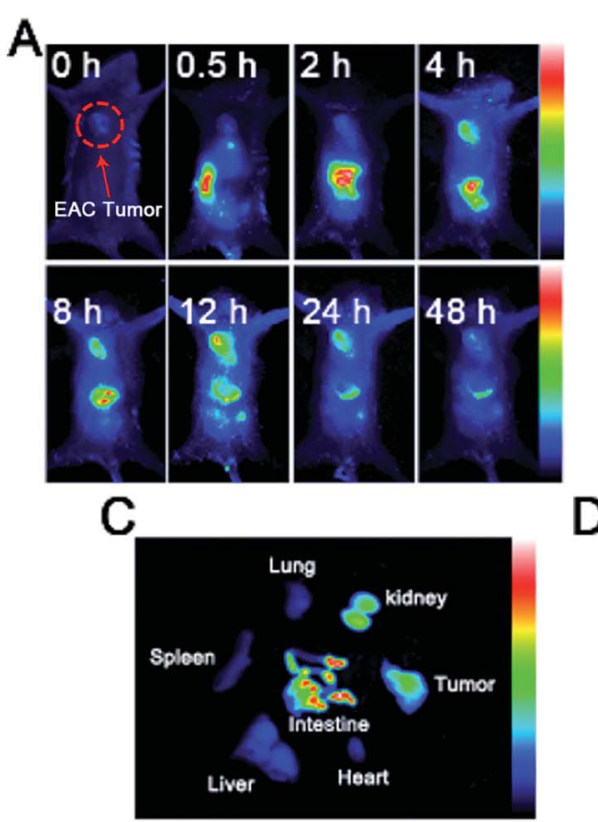

B
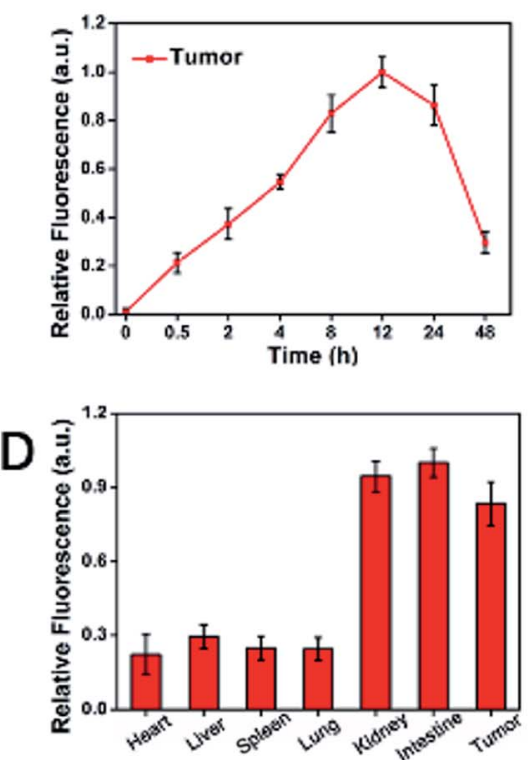

Fig. 9 (A) In vivo fluorescence images of CuS-apoferritin-MBA in the EAC tumor-bearing mice model within $24 \mathrm{~h}$. (B) Fluorescence intensity of CuS-apoferritin-MBA in tumor-bearing mice at different time post-injection (C) the ex vivo fluorescence images of isolated organs (tumor, heart, liver, spleen, lung, kidney, and intestine) from the tumor-bearing mice at $12 \mathrm{~h}$ post-injection of CuS-apoferritin-MBA. (D) Fluorescence intensity of isolated organs (tumor, heart, liver, spleen, lung, kidney, and intestine) from the tumor-bearing mice at $12 \mathrm{~h}$ post-injection of CuS-apoferritinMBA. 

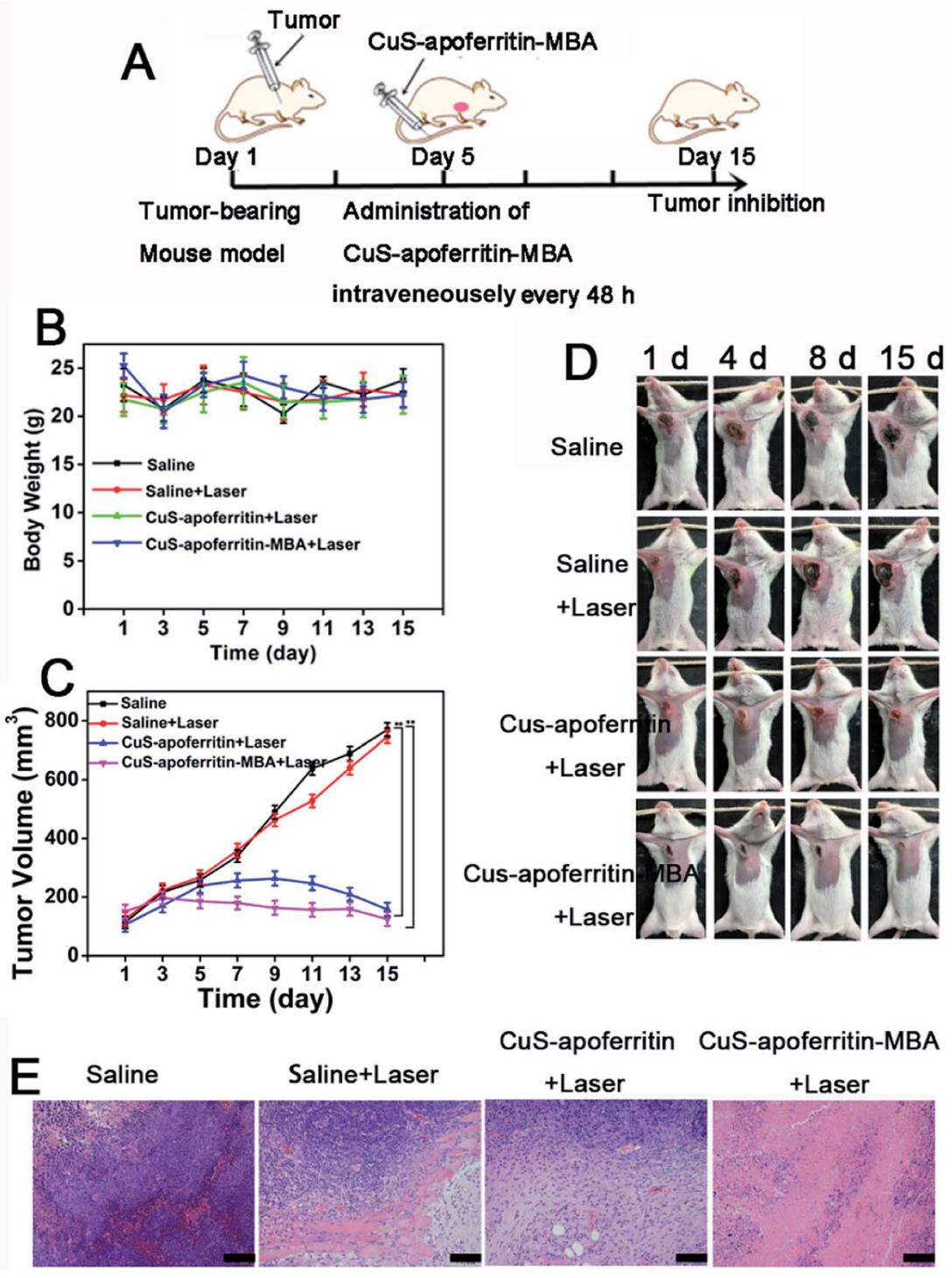

CuS-apoferritin CuS-apoferritin-MBA

10 (A) The experimental scheme to evaluate the anti-tumor effect of CuS-apoferritin-MBA. (B) The body weight of tumor-bearing mice during 15 days treatment of saline, saline + laser; CuS-apoferritin + laser and CuS-apoferritin-MBA + laser. (C) The relative tumor volume in various mice groups after PTT; (D) the images of the tumor-bearing mice after PTT. (E) The tumor images isolated from tumor-bearing mice after treatment of saline, Saline + laser, CuS-apoferritin + Laser and CuS-apoferritin-MBA + Laser. Error bar is $50 \mu \mathrm{m}$.

a temperature of 29.6 and $31.0{ }^{\circ} \mathrm{C}$, respectively. After 5 min of laser irradiation, the temperature in the tumors increased to 36.3 and $40.4{ }^{\circ} \mathrm{C}$ for CuS-apoferritin and CuS-apoferritin-MBA groups respectively, which exceeds the damage threshold needed to induce irreversible tissue damage. However, the PBStreated group in Fig. 7B only had a temperature increase of $3.4{ }^{\circ} \mathrm{C}$, which is insufficient to damage tumor irreversibly.

\subsection{Biodistribution and tumor-targeting ability of CuS- apoferritin-MBA in vivo}

A NIR imaging approach was used to investigate tumor targeting and in vivo distribution of CuS-apoferritin-MBA in nude mice. Fig. 8A shows the dynamic distribution of CuSapoferritin-MBA in normal mouse models at $0.5 \mathrm{~h}, 2 \mathrm{~h}, 4 \mathrm{~h}$, $8 \mathrm{~h}, 12 \mathrm{~h}, 24 \mathrm{~h}$, and $48 \mathrm{~h}$ post-injection. The obvious fluorescence signal appeared in the liver of the normal mice just after $0.5 \mathrm{~h}$ from injection; then, the fluorescence signal was observed in the intestine. The results suggested that CuSapoferritin-MBA excreted from the mice through the liverintestine excretion path way. To confirm the in vivo result, the mice were sacrificed and the main organs were collected and imaged at 4 h, 8 h, 12 h, 24 h, and 48 h $(n=5)$. Fig. 8B displays the in vitro fluorescence images of the main tissues from the CuS-apoferritin-MBA treated group at different post-injection times. Strong fluorescence signals appeared in intestine at each time interval.

Tumor-bearing mice were utilized to investigate the tumor specificity of CuS-apoferritin-MBA. As shown in Fig. 9A, CuSapoferritin-MBA initially spread over tumor-bearing mice body within $8 \mathrm{~h}$ of post-injection. The fluorescence signal reached peak 


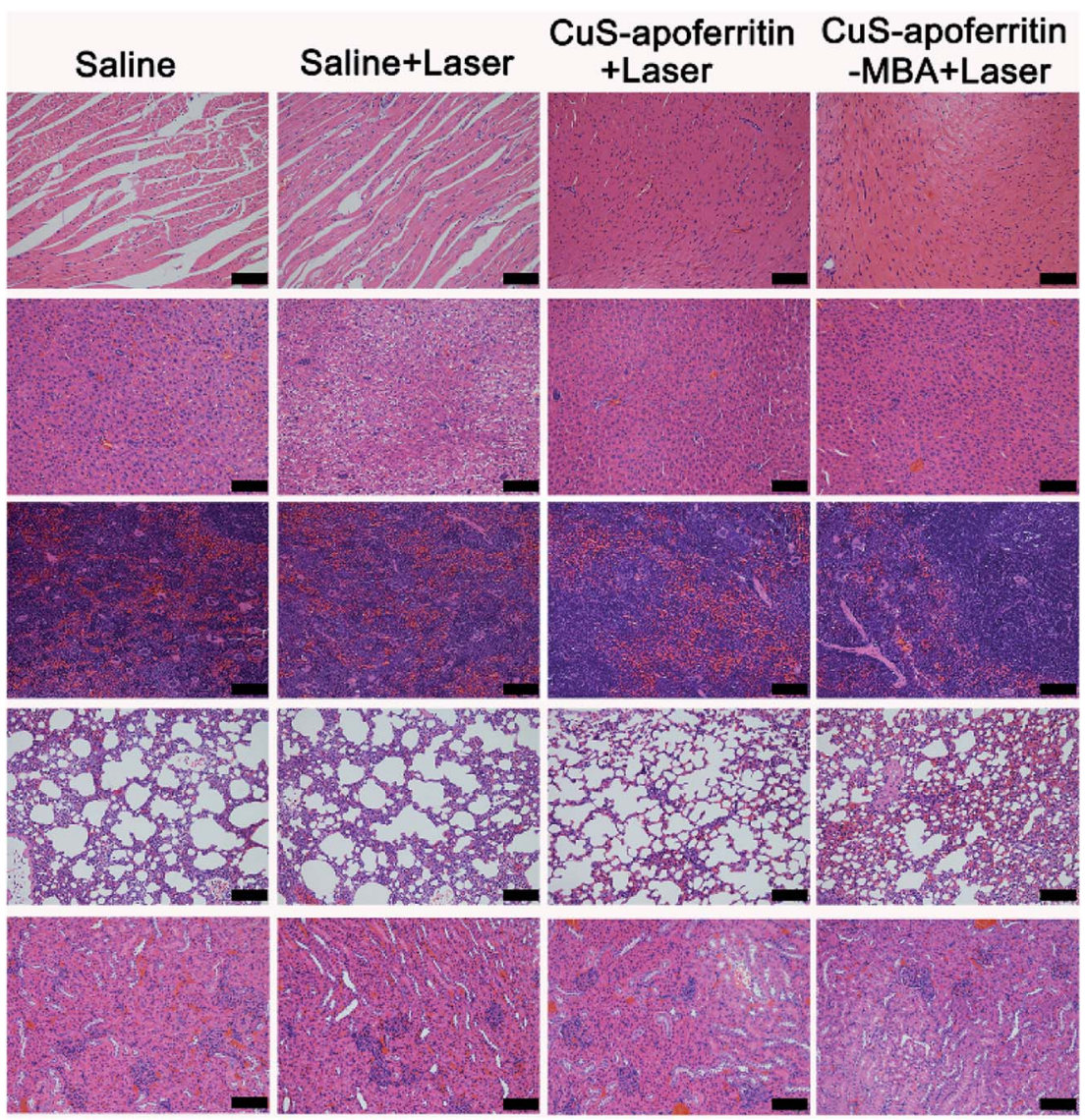

Fig. 11 The histological images of the main organs (heart, liver, spleen, lung, and kidney) of the mice after treated with saline, saline + laser, CuS-apoferritin + laser and CuS-apoferritin-MBA + laser. Error bar is $50 \mu \mathrm{m}$.

intensity at $12 \mathrm{~h}$. Fluorescence intensity in specific ROIs from tumors were collected to study the targeting efficacy of the probes semi-quantitatively (Fig. 9B). The maximum fluorescence of CuS-apoferritin-MBA arrived at $12 \mathrm{~h}$ post-injection, indicating CuS-apoferritin-MBA possesses good tumor targeting ability. The in vitro fluorescence images of the main tissues from CuSapoferritin-MBA treated groups at $12 \mathrm{~h}$ post-injection are shown in Fig. 9C. Obviously, CuS-apoferritin-MBA treated group shows much strong fluorescence in tumors. And the semiquantitative analysis demonstrates that there is obvious discrepancy of tumor fluorescence at different time intervals for CuS-apoferritin-MBA treated groups (Fig. 9D).

As an agent carrier, apoferritin may effectively carry a cargo towards a tumor due to high affinity with its specific receptors, TfR1. The apoferritin-encapsulated gadolinium was suggested by Makino et al. as a possible candidate for a new MRI contrast agent. ${ }^{32}$ Gadolinium was efficiently encapsulated into the apoferritin cavity and enhanced the T1 relativity to tenfold higher than the commercially used contrast agent gadolinium-DOTA. Moreover, the in vivo blood clearance time of apoferritin coated cargo can be prolonged. An increased accumulation of this complex was observed mainly in the tumor region due to active targeting via acceptor-ligand affinity and passive targeting via enhanced permeability and retention effects. We have shown that CuS-apoferritin-MBA can specifically target tumor cells that overexpress TfR1 (Fig. 5D). To confirm the specific binding of this nanocomposite in vivo, tumor imagings were performed on TfR1 overexpressed EAC tumor-bearing mouse models. As expected, EAC tumors showed significant fluorescence only after $4 \mathrm{~h}$ post-injection of CuS-apoferritin-MBA (Fig. 9A), indicating a specific binding of CuS-apoferritin-MBA to TfR1 on an animal level.

\subsection{Therapy evaluation of CuS-apoferritin-MBA in tumor- bearing mice}

Fig. 10A illustrates the experimental scheme to evaluate the anti-tumor effect of CuS-apoferritin-MBA. The samples were intravenously injected into the mice at scheduled intervals. The size of tumor and weight of the mice were monitored every two days. Body weight is displayed in Fig. 10B; results show that there was no obvious toxicity of CuS-apoferritin-MBA. As indicated in Fig. 10C, tumors of CuS-apoferritin and CuS-apoferritin-MBA groups became smaller within 5 days after laser exposure. And the tumor inhibition ratio of the CuS-apoferritin-MBA group is $67.8 \%$. By contrast, tumor volume increased rapidly over time in groups of CuS-apoferritin and CuS-apoferritin-MBA. These results indicated that CuS-apoferritin-MBA under laser exposure could inhibit tumor growth effectively due to higher thermal conversion efficiency. 
Furthermore, no tumor regrowth was observed in the CuS-apoferritin-MBA group within 15 days after treatment, thereby further confirming that a CuS-apoferritin-MBA injection with laser irradiation could completely ablate tumors in mice. All mice behaved normally after treatment. In the photothermal treatment group, black scars were noticed at the original tumor sites, but they fell off within 7-10 days post laser irradiation (Fig. 10D).

Histology examination of tumor slices by Hematoxylin-eosin (H\&E) staining revealed that tumor structure in the CuSapoferritin-MBA injected group was severely damaged right after laser irradiation (Fig. 10E). Moreover, H\&E stained images of main organs from CuS-apoferritin-MBA injected healthy mice also suggest that CuS-apoferritin-MBA did not induce appreciable toxic side effects to treated animals (Fig. 11).

Thanks to high biocompatibility, low immunogenicity, and good pharmacokinetics profile, apoferritin showed a promising application in PTT. ${ }^{33,34}$ Most of the photothermal agents show biotoxicity, high immunogenicity, non-biodegradability, and poor pharmacokinetics, which strongly affect their clinical application. $^{35,36}$ We demonstrated that CuS-apoferritin-MBA presented favorable biocompatibility, prolonged circulation time, and enhanced tumor therapy efficiency. Mostly importantly, CuS-apoferritin-MBA together with NIR laser irradiation showed significant photothermal efficiency on EAC tumorbearing mouse models (Fig. 10).

\section{Conclusions}

In conclusion, a unique photothermal agent (CuS-apoferritinMBA) was developed by a conventional synthesis method. Apoferritin as a biotemplate was used to control the size of CuS nanoparticles, and NIR dye (MBA) was used to enhance the photothermal efficiency of CuS-apoferritin. The prepared CuSapoferritin-MBA displayed good water dispersion, good biocompatibility, and favorable tumor-targeting capability. Both of in vitro and in vivo anti-cancer evaluations of CuSapoferritin-MBA validated that this photothermal agent is highly efficient for photothermal therapy.

\section{Conflicts of interest}

There are no conflicts to declare.

\section{Acknowledgements}

The authors are grateful to the Natural Science Foundation Committee of China (NSFC 81671803), a project supported by the National Key Research and Development Program (Grant No. 2017YFC0107700), the Outstanding Youth Foundation of Jiangsu Province (BK20170030) and funded by Postgraduate Research \& Practice Innovation Program of Jiangsu Province and the Priority Academic Program Development of Jiangsu Higher Education Institutions for their financial support.

\section{References}

1 P. Zhang, C. Hu, W. Ran, J. Meng, Q. Yin and Y. Li, Theranostics, 2016, 6, 948-968.

2 M. Xiao, Y. M. Li, M. C. Allen, D. D. Deheyn, X. J. Yue, J. Z. Zhao, N. C. Gianneschi, M. D. Shawkey and A. Dhinojwala, ACS Nano, 2015, 9, 5454-5460.

3 J. Lin, S. J. Wang, P. Huang, Z. Wang, S. H. Chen, G. Niu, W. W. Li, J. He, D. X. Cui, G. M. Lu, X. Y. Chen and Z. H. Nie, ACS Nano, 2013, 7, 5320-5329.

4 Z. B. Zha, Z. J. Deng, Y. Y. Li, C. H. Li and J. R. Wang, Nanoscale, 2013, 5, 4462-4467.

5 S. S. Ren, X. Cheng, M. K. Chen, C. Liu, P. C. Zhao, W. Huang, J. He, Z. Y. Zhou and L. Y. Miao, ACS Appl. Mater. Interfaces, 2017, 9, 31509-31518.

6 S. K. Misra, I. Srivastava, I. Tripathi, E. Daza, F. Ostadhossein and D. Pan, J. Am. Chem. Soc., 2017, 139, 1746-1749.

7 J. Budhathoki-Uprety, R. E. Langenbacher, P. V. Jena, D. Roxbury and D. A. Heller, ACS Nano, 2017, 11, 3875-3882.

8 K. Yang, J. Wan, S. Zhang, B. Tian, Y. Zhang and Z. Liu, Biomaterials, 2012, 33, 2206-2214.

9 J. B. Song, X. Y. Yang, Z. Yang, L. S. Lin, Y. J. Liu, Z. J. Zhou, Z. Y. Shen, G. C. Yu, Y. L. Dai, O. Jacobson, J. Munasinghe, B. Yung, G. J. Teng and X. Y. Chen, ACS Nano, 2017, 11, 6102-6113.

10 M. R. K. Ali, Y. Wu, T. G. Han, X. L. Zang, H. P. Xiao, Y. Tang, R. H. Wu, F. M. Fernández and M. A. El-Sayed, J. Am. Chem. Soc., 2016, 138, 15434-15442.

11 A. Camposeo, L. Persano, R. Manco, Y. Wang, P. D. Carro, C. Zhang, Z. Y. Li, D. Pisignano and Y. N. Xia, ACS Nano, 2015, 9, 10047-10054.

12 L. D. Trizio, H. B. Li, A. Casu, A. Genovese, A. Sathya, G. C. Messina and L. Manna, J. Am. Chem. Soc., 2014, 136, 16277-16284.

13 H. X. Rao, W. H. Sun, S. Y. Ye, W. B. Yan, Y. L. Li, H. T. Peng, Z. W. Liu, Z. Q. Bian and C. H. Huang, ACS Appl. Mater. Interfaces, 2016, 8, 7800-7805.

14 L. M. Yang, Y. H. Tang, D. F. Yan, T. Liu, C. B. Liu and S. L. Luo, ACS Appl. Mater. Interfaces, 2016, 8, 169-176.

15 M. Chen, S. Z. Chen, C. Y. He, S. G. Mo, X. Y. Wang, G. Liu and N. F. Zheng, Nano Res., 2017, 10, 1234-1248.

16 Y. Tia n, J. Zhang, S. Tang, L. Zhou and W. Yang, Small, 2016, 12, 721-726.

17 C. Wang, H. Xu, C. Liu, Y. M. Liang, Z. W. Li, G. B. Yang, H. Li, Y. G. Cheng and Z. Liu, ACS Nano, 2013, 7, 6782-6795.

18 S. L. Li, X. Y. Wang, R. Hu, H. Chen, M. Li, J. W. Wang, Y. X. Wang, L. B. Liu, F. T. Lv, X. J. Liang and S. Wang, Chem. Mater., 2016, 28, 8669-8675.

19 M. Molina, S. Wedepohl and M. Calderón, Nanoscale, 2016, 8, 5852-5857.

20 S. Pfaffen, J. M. Bradley, R. Abdulqadir, M. R. Firme, G. R. Moore, N. E. Le Brun and M. E. P. Murphy, J. Biol. Chem., 2015, 290, 28416-28427.

21 M. Bellini, S. Mazzucchelli, E. Galbiati, S. Sommaruga, L. Fiandra, M. Truffi, M. A. Rizzuto, M. Colombo, 
P. Tortora, F. Corsi and D. Prosperi, J. Controlled Release, 2014, 196, 184-196.

22 L. Turyanska, T. D. Bradshaw, M. Li, P. Bardelang, W. C. Drewe, M. W. Fay, S. Mann, A. Patan and N. R. Thomas, J. Mater. Chem., 2012, 22, 660-665.

23 Q. Chen, C. Wang, Z. X. Zhan, W. W. He, Z. P. Cheng, Y. Y. Li and Z. Liu, Biomaterials, 2014, 35, 8206-8214.

24 M. Liang, K. Fan, M. Zhou, D. Duan, J. Zheng, D. Yang, J. Feng and X. Yan, Proc. Georgian Natl. Acad. Sci., 2014, 111, 14900-14905.

25 S. R. Radoshitzky, J. Abraham, C. F. Spiropoulou, J. H. Kuhn, N. Dan, W. H. Li, J. Nagel, P. J. Schmidt, J. H. Nunberg, N. C. Andrews, M. Farzan and H. Choe, Nature, 2007, 446, 92-96.

26 H. Choe, S. Jemielity, J. Abraham, S. R. Radoshitzky and M. Farzan, Curr. Opin. Microbiol., 2011, 14, 476-482.

27 D. Moss, L. W. Powell, P. Arosio and J. W. Halliday, J. Lab. Clin. Med., 1992, 120, 239-243.

28 S. W. Hulet, S. Menzies and J. R. Connor, Dev. Neurosci., 2002, 24, 208-213.
29 J. Liu, G. Hu, D. Chen, A. Y. Gong, G. S. Soori, T. J. Dobleman and X. M. Chen, Oncogenesis, 2013, 2, 1-10.

30 Z. T. Wang, P. Huang, O. Jacobson, Z. Wang, Y. J. Liu, L. S. Lin, J. Lin, N. Lu, H. M. Zhang, R. Tian, G. Niu, G. Liu and X. Y. Chen, ACS Nano, 2016, 10, 3453-3460.

31 L. Liang, S. W. Peng, Z. W. Yuan, C. Wei, Y. Y. He, J. R. Zhen, Y. Q. Gu and H. Y. Chen, RSC Adv., 2018, 8, 6013-6026.

32 A. Makino, H. Harada, T. Okada, H. Kimura, H. Amano, H. Saji, M. Hiraoka and S. Kimura, Nanomedicine, 2011, 7, 638-646.

33 J. Xie, Z. P. Zhen and W. Tang, Cancer Res., 2013, 73, 4513. 34 H. C. Yao, L. Su, M. Zeng, L. Cao, W. W. Zhao, C. Q. Chen, B. Du and J. Zhou, Int. J. Nanomed., 2016, 11, 4423-4438.

35 A. Yuan, J. H. Wu, X. L. Tang, L. L. Zhao, F. Xu and Y. Q. Hu, J. Pharm. Sci., 2013, 102, 6-28.

36 S. Wang, Q. Zhang, X. F. Luo, J. Li, H. He, F. Yang, Y. Di, C. Jin, X. G. Jiang, S. Shen and D. L. Fu, Biomaterials, 2014, 35, 9473-9483. 